NEWS

\title{
Europe spells out action plan for emissions targets
}

Power stations in Europe will have to pay for permits to release carbon dioxide as soon as 2013, the European Commission announced last week. But although heavy industries will be included in the European Union's emissions trading scheme (ETS), the commission stopped short of making sectors such as steel and paper pay for their permits.

Commission president José Manuel Barroso proposed a package of market-based and regulatory measures to the European Parliament and Council of Ministers in Brussels on 23 January. He says that the package will bolster the European Union's leading role in tackling climate change and secure its future energy supply. If approved, the proposals could become law in the European Union's 27 member states as soon as 2009.

"This is a strong proposal - stronger than I would have expected - and a very positive step forward in terms of climate protection," says Michael Grubb, a specialist on climatechange policy at Imperial College London.

The details of the plan for how to cut greenhouse-gas emissions across the European Union by at least $20 \%$ by 2020 were hotly contested in Brussels. At the plan's core is an amendment of the ETS, first introduced in 2005, which has so far failed to facilitate a shift to low-carbon technologies. To give the ETS some teeth, the commission proposes a sweeping reform: most importantly, that power plants and energyintensive industries will no longer receive a generous allocation of emissions 'allowances' free of charge. Instead, they will have to buy all allowances at auctions organized by the member states. Heavy industries that face strong international competition, including steel, aluminium, concrete and paper, will still get free allowances - although a consultation in 2011 will review this exemption.

Under current rules, which will remain valid until 2012, the 10,000 or so facilities that participate in the ETS get free emissions allowances from national packages that governments negotiate for every year. If a plant emits in excess of its free allocation, though, it must buy additional allowances on the emissions market. An allowance to emit one extra tonne of $\mathrm{CO}_{2}$ in the 2008-12 trade period last week cost around $€ 21$ (US\$31) on Europe's carbon-future markets.

Because national governments have in the past tended to over-allocate free allowances, the commission suggests doing away with national allocation plans and introducing instead a single cap throughout the European Union that is based on historic emissions and expected trends. "Centralizing the allocation of emissions rights may prove the most contentious point in the proposals," Grubb says. "But I think there is limited [room for] manoeuvre

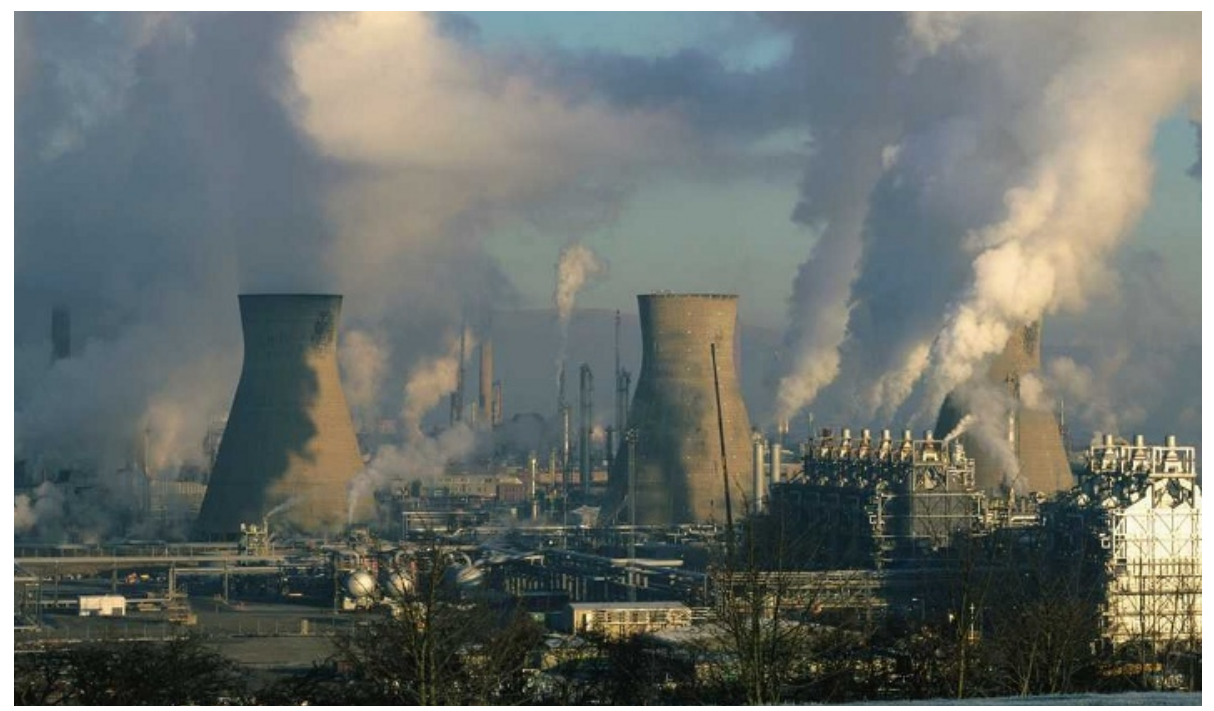

Power plants in Europe will no longer receive free allowances for their greenhouse-gas emissions.
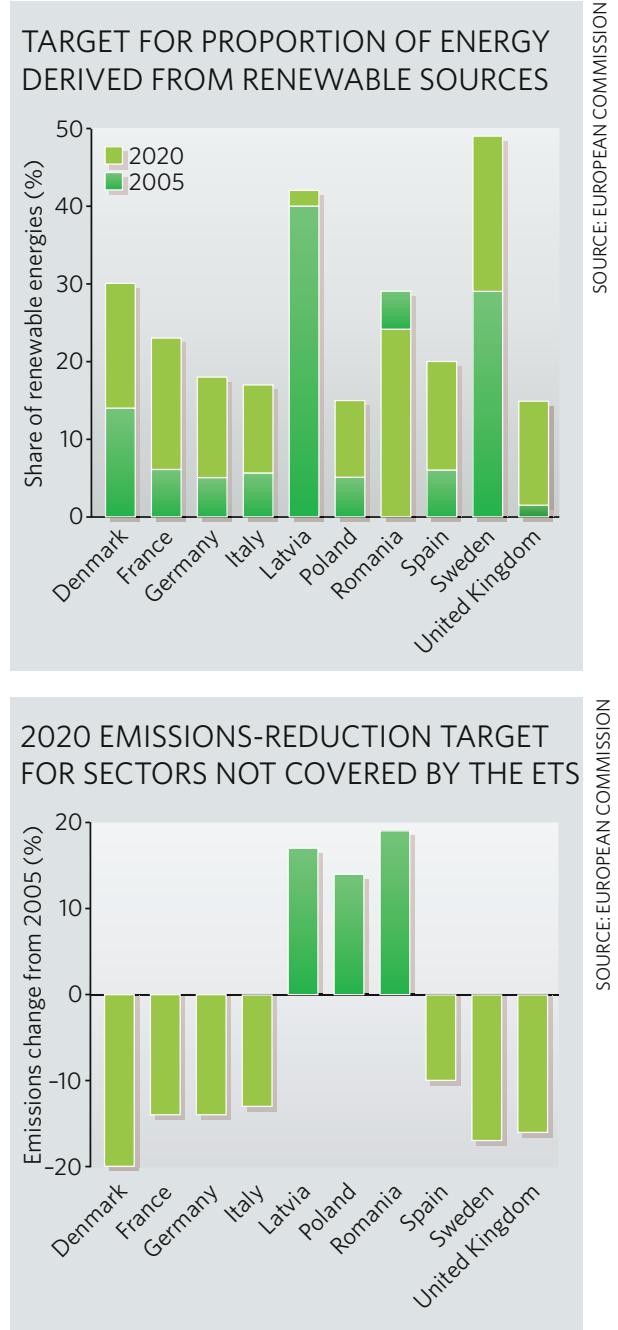

for the member states to unpick these proposals - they are in a weak position, given how they have behaved in the past."

In addition, the overall number of emissions allowances will be substantially reduced during the third trading phase, which starts in 2013. The commission suggests putting 1,974 million tonnes of tradable emissions allowances on the market in 2013, compared with 2,080 million tonnes today, and then reducing this yearly to 1,720 million tonnes by 2020 . This would mean that emissions by all participants in the ETS - which account for around half of the European Union's total $\mathrm{CO}_{2}$ emissions - would be reduced by $21 \%$ relative to 2005 . The price of emissions allowances is expected to rise as they become scarcer, making it increasingly profitable for plant owners to switch to cleaner fuels, or to invest in clean-energy technologies such as carbon capture and storage.

The commission's proposals got crossparty support in the European Parliament last week, even though the cost of the package is estimated at $€ 90$ billion or $0.6 \%$ of gross 
domestic product in 2020. "There is a cost, but it is manageable," Barroso told parliament. "Implementing the package will cost $€ 3$ per week per EU citizen. Inaction will cost them $€ 50-60$ per week." The commission estimates that "by 2020 a household's overall energy bill would rise by an average of $€ 150$ per year".

"Finally, we move from targets to tools," says Lena Ek, a Swedish member of the Liberal Democrat party. British parliamentarian Graham Watson called the package "the most important act of the Barroso commission so far".

Auctioning emissions allowances could generate state revenues of up to $€ 50$ billion per year. At present, roughly the same sum is tantamount to a windfall profit for the power industry, which has passed on to consumers the 'costs' of emissions trading. The commission has not specified how member states should use the extra money, but does suggest that climate and energy research should benefit.

"Energy research and development in the European Union is shamefully low," says Ottmar Edenhofer, an economist at the Potsdam Institute of Climate Impact Research in Germany. "The proposed scheme will increase pressure on industry to develop lowemissions technologies. The revenues from auctioning emissions rights should be channelled into research and innovation."

The emissions market is volatile and has reacted nervously to political interference in the past, but experts say that the scheme will benefit from the amendments. "Industry, banks and investors need planning reliability," says Stefan Kleeberg, a carbon-market analyst with the 3C group near Frankfurt, Germany. "Knowing the post-2012 trading rules early will stabilize the market and will ultimately make it more efficient." Realistically, a price of $€ 24-30$ per tonne of $\mathrm{CO}_{2}$ can be expected at auctions, he says.

Other proposals include sectors not covered by the ETS, such as transport, agriculture and buildings, which will on average have to reduce emissions by merely $10 \%$ of 2005 levels by 2020 . Wealthier member states will need to cut more emissions than poorer countries.

In addition, the overall share of renewable energy in the European Union's final energy consumption is to increase from $8.5 \%$ to $20 \%$, with specific targets for each member state. Countries that fail to deliver the legally binding target might face financial penalties.

The commission also calls for a $10 \%$ biofuel component in vehicle fuel by 2020 . As excessive production of raw materials for biofuels has sparked serious environmental concerns, it will outline stringent sustainability criteria for their use.

Quirin Schiermeier

See Editorial, page 499.

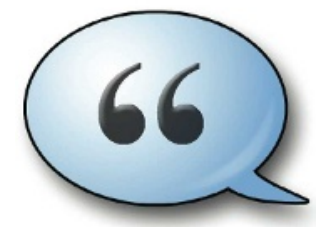

HAVE YOUR SAY

Comment on any of our news stories, online.

www.nature.com/news

national science adviser

The Canadian government is closing its Office of the National Science Advisor at the end of March, after just four years of service. The top-level science and technology adviser post will also be abolished in the move; it was already sidelined in 2006 when the new conservative government reassigned the adviser's responsibilities from reporting to the prime minister to reporting to the industry minister.

"I'm dismayed that the office is disappearing after four years and that it hasn't become a permanent fixture in science and technology in Canada," says Arthur Carty, who has held the post since its inception. Carty decided to retire from public office when he was told that the government was discontinuing the position.

Industry Canada said that the decision to phase out the office followed the establishment of the Science, Technology and Innovation Council (STIC) in June 2007. "The STIC will function as a single committee, providing the government with independent and integrated advice on science and technology," it said. It consists of a chair, Howard Alper, a chemistry professor at the University of Ottawa who is former president of the Royal Society of Canada, and 17 members, including university leaders, scientists, industry executives and government ministers.

Canadian scientists are undecided as to whether the council can replace the role and function of a national science adviser. "I don't think what they have now in its place is any more likely to succeed than anything else," says David Anderson, director of the Guelph Institute for the Environment in Ontario and former federal environment minister.

"The jury is still out," says Elizabeth Dowdeswell, chair of the scientific advisory committee of the Council of Canadian Academies in Ottawa, Ontario.

Some scientists have criticized the move as evidence of the government's lack of interest in science and understanding of how it is done. Anderson says that Carty must have had a hard time giving science advice while the administration was trying to discredit the science of climate change.

Carty is a British-born organometallic chemist who ran the National Research Council Canada from 1994 to 2004. When Prime Minister Paul Martin revived the science adviser post to harness Canada's science potential and offer insight on international science issues, he appointed Carty. It was the first such post in Canada for 30 years (see Nature $427,91 ; 2004)$. The office's small budget and vague mandate soured its chance of success from the start. Its finances, including salaries, hovered around Can $\$ 1$ million (US\$1 million), and the office didn't secure any permanent staff to help Carty until its third year.

During his tenure, Carty spearheaded the 2005 creation of the Council of Canadian Academies, like the US National Academy of Sciences. The council provides independent assessments of the science underlying key issues, but does not make recommendations to the government. Carty helped to establish Canada as a leader in the International Polar Year, ensuring that it provided $\$ 150$ million in funding. He also represented Canada at the Carnegie Group's meetings of science ministers and advisers.

But some work, including a national consultation on how major science initiatives should seek funding, "never saw the light of day", Carty told Nature. "I don't really think the government has understood the role that a national science adviser - or that office - can play."

The news comes shortly after the government sacked Linda Keen, the president of the Canadian Nuclear Safety Commission, the country's independent nuclear watchdog. Critics have said that Keen was fired for "doing her job". The move suggests that the independence of advisers and committees is on shaky ground, says Anderson. Hannah Hoag 